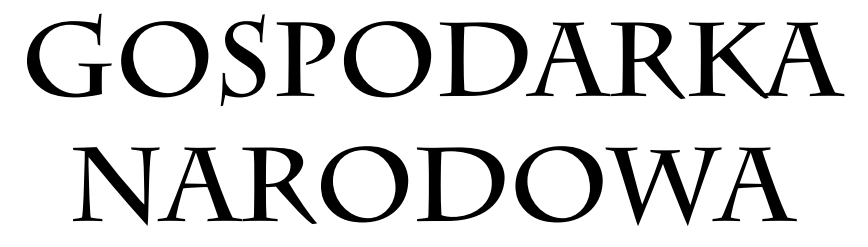

Rok LXXX/XXI

lipiec-sierpień

2011

s. $1-20$

Janusz SAWICKI*

\title{
Debt reduction in the eurozone
}

\section{The different forms of debt reorganization ${ }^{1}$}

Sovereign debt problems are not new. They have troubled nations for centuries. What has changed in the past few decades is the source of sovereign debt financing and the approach to reorganizing that debt in the case of illiquidity or insolvency. Before Brady bonds were introduced in 1989, sovereign debt was typically provided bi-laterally through country to country sovereign credit or banking credits which may or may not have been guaranteed by the government or government institutions [Krugman, 1998]. The Brady plan introduced a new instrument in the form of bonds issued by a country as a result of a restructuring of its defaulted bank debt. And bonds began to play an important role in raising funds not only for middle-income countries. Today the sovereign debt is funded largely by state institutions (such as the Treasury or Ministry of Finance) issuing bonds to banks and other financial organizations. By 20102 quarter the foreign debt of middle income countries amounted to USD 3.31 trillion, of which USD 1.5 trillion were international debt securities ${ }^{2}$ representing an increase of about 5 times over the last 20 years. As financial markets have taken over from banks in fundraising there has been a fundamental change of players in debt negotiations. And new challenges have emerged in restructur-

The Author works at the Institute for Market, Consumption and Business Cycles Research in Warsaw, e-mail: januszsyta@neostrada.pl. He was Deputy Finance Minister of Poland in the first years of the economic transformation of the Polish economy and Polish government chief debt negotiator in the Paris Club and the London Club. The paper was submitted in June 2010.

1 The term reorganization is used by the Paris Club [Béranger-Lachand, 2001].

2 BIS statistics - amounts by residence of issuer outstanding at September 2010. 
ing sovereign debt in the form of private bonds and short-term interbank lines rather than syndicated medium-long term bank loans. The market practices of bondholders often clashed with the conventional process and administrative management of debt rescheduling seen in the 1980s.

Sovereign debt problems have historically been addressed by using various methods including debt refinancing, debt restructuring and debt reduction.

Debt refinancing (often described as a bailout), when referring to sovereign debt, is loosely used to describe an extensive official support package which fills the entire financing gap. Bailouts usually involve international financial institutions which provided resources designed to restore investors' confidence and market access and thus avoid the need for more restructuring and further more coercive forms of private sector involvement [Roubini, 2001]. The conditions on which the new money is provided are more often than not better then the market requirements and could also diverge form the original terms.

Debt restructuring simply postpones/extends the schedule of originally incurred debt repayments without reducing the total level of the debt. By the 1980s it appeared that debt restructuring, by simply altering the timing of repayments through interest capitalization, in fact increased the quantity of debt $^{3}$ and caused the debt-to-GDP ratio to increase over time.

In the debt reduction procedure (described as a bail-in) in addition to refinancing and rescheduling the payments of the total amount of debt is reduced, something for which the creditors agree to incur the cost. Debt reduction can be achieved through a number of mechanisms including reducing the total amount due and/or by applying below-market interest rates, not capitalizing interest rates, moratorium interest or even forgiving past due interest. The bailout and the bail-ins can also be tied to the creditors providing new money for the borrower to use to repay part of its debt and/ or to finance necessary adjustment programs [Roubini at al., 2004].The above requires that the international financial institutions or/ and governments actively support debt reorganisation process.

The structure of bailout resources and /or the level of "haircut" inflicted on the creditor should theoretically depend on distinguishing whether there is a problem of illiquidity or an insolvency of the economy. However it is not so easy to make such a distinction [Miller at al., 1999]. Most often it is not either/or. Illiquid countries may have serious macro and structural problems and countries that look insolvent may not be so if they implement serious adjustment and reform policies. It is also harder to be objective in applying the solutions of debt restructuring and reduction when the country is large and/ or systemically important. In these cases there is a political tendency to consider the country as "illiquid" rather than "insolvent" as it is then easier to explain why public money is involved in the bailout process. That is also the case in the present eurozone debt situation. When country gets into trouble

3 In Poland e.g. continuous restructurings of the sovereign debt within 1980's increased the debt level by ca $100 \%$. 
because is systemically important, the political pressure to bailout this country (usually with an exceptionally large package of public money) is common.

In the classic restructuring procedure banks, depending on the country supervisory authorities regulations ${ }^{4}$, shored up the value of their outstanding loans while continuing involuntary lending to enable the debt laden countries to pay interest. Even when supported by the "sovereign risk hypothesis", the creditors' key objective was to end their involvement as quickly as possible. Therefore some of the involved creditors were selling their foreign debt through secondary markets, accepting losses in the process 5 .

It is difficult to argue against the principle that investors in bonds issued by sovereign governments should suffer haircut if the government cannot redeem its bonds. This would represent a "bail-in" as opposed to a bailout (where banks and bondholders are paid total amounts due at the expense of the public sector). However, the involvement of bondholders on the basis of equal burden sharing is still a delicate matter ${ }^{6}$. Bondholders are reluctant to be graded pari-passu with other creditors ${ }^{7}$. In addition, they are a widely scattered group and meetings are difficult to arrange. There is a problem of representing sub-groups within the main body of bondholders. The spontaneous reaction of bondholders, or groups of bondholders, is to take legal action (as in the case of Peru vs. Elliot) [Krueger, 2001], [Fukuda, 2008], [Berry, 2006]. There are other difficulties concerning bond debt restructuring. For example, differences between the treatment of external and domestic debt; seniority and the selection of priority of bond holders; and the interconnection between sovereign and private debt [Hornbeck, 2004]. Some of these problems can be only partially solved by using collective action clauses (CAC) standards [Haldane at al., 2004].

\section{The practical implementation of the debt reorganization}

There appear to be two distinct periods in the history of debt restructuring in "medium developed" countries 8 . (Low-income countries, on the other hand, are treated differently as debt rearrangement in such countries is perceived as political and humanitarian assistance rather than as a business contract [Kalonga, 1999], [Gelpern, 2007], [Helleiner, 1989]. In the first period, up to

4 The varied provisioning regulations made it difficult to achieve the comparability of treatment between the creditors.

5 It is worth remembering that Polish private debt before the reduction was traded with the 70- $80 \%$ discount.

6 Similar problem relates to all interbank operations which were usually excluded from the debt reorganization.

7 Polish case lost by Bank Handlowy S.A. in the Swiss courts in 1985 has confirm that bonds cannot be rescheduled on the same terms as loans.

8 The financial crises of the1990s affected almost exclusively developing countries: the Mexican crisis of 1994-1995, the 1997-1998 Asian crisis, Russian crisis of 1998 Brazilian crisis of 1999, Turkish crisis of 2000, the Argentine crisis of 2001-2002 crisis Brazil again in 2002. 
the end of the 1980s Latin America crisis, sovereign debt was resolved: (i) first through debt refinancing (bailing out) and (ii) by means of debt restructuring. However, as the bailout did not allow the debt-laden countries to "grow out of their debt" the only result of this operation was growing indebtedness [Loomis, 1985]. Eventually the increasing level of unpaid amounts, which were due mainly to American banks, became a public problem [Taleb, 2010]. The governments could not allow the financial systems to be considerably weakened nor could they let the prolonged crisis lead to political destabilization of the affected region. Reinhart and Rogoff [2009] wrote that when a credit bubble finally bursts, private debt becomes public affair ${ }^{9}$. Consequently the Brady scheme, allowing for debt reduction (bail - in), was invented. It dealt with the root of the problem. It also provided an easy exit for the creditor banks involved. One should remember however it took almost eight years before debt reduction became politically acceptable. It happened when: (i) banks understood that throwing good money after the bad and rescheduling incurred arrears and past due interest would not lead to solvency for either the creditors or the debtors (ii) the private creditors were eventually prepared to accept a haircut of $30-45 \%$ (after having restructured their books, supported by the regulators decisions) (iii) debtor countries accepted the adjustment program hammered out with the IMF.

This was the first time that debt negotiations incorporated debt reduction as an important element of the arranged solution. Brady exit bonds were collateralised with American Government zero coupon bonds. Most of the money needed to guarantee Brady's was in fact provided by the IMF as a part of the package. The debt reduction was conditional on economic policy changes. It did not directly involve taxpayer's money. It was important that the package was constructed so that the debt laden countries could attract new foreign capital which they needed to resume their growth.

Admittedly in the Latin American case, the creditor banks were easier to summon than they are today in the eurozone situation so the free rider's hazard was relatively small. The banks had time to create reserves which made the haircut less painful. The role of IMF in the past crisis was unquestionable. So it was easier to create the platform for the negotiations to be lead by the debt manager and, as it was largely American banks that were involved, the leading position of the American Treasury was undisputed. The Brady Plan changed many things, including the source of financing for sovereign debt. Bank financing, in the form of syndicated loans, dried up and banks remained out of the business for a long time. Many of them, particularly in the United States, sold off the new securities which they received in the Brady debt swap to specialized market firms.

In April 1991, Poland became the first European and the first middle income country to successfully negotiate a reduction of its sovereign debt when 17 gov-

9 In 1982 the exposure of the major US banks as percentage of their capital in five Latin America countries exceeded $150 \%$ and was rising. 
ernments agreed to decrease the official debt of Poland by 50 per cent of NPV [Sawicki, 2010]. This decision to reduce Polish debt came two years after the Brady Plan had been implemented. The Brady Plan was viewed as an unparallel success and a breakthrough in debt reorganization and in sovereign debt financing. Both of these situations, the London Club and the following Paris Club debt reduction, are worth considering as the European Union chaotically struggles to manage the current debt crisis.

The Polish case was politically sensitive and thus received "special treatment". Poland had then emerged from a socialist economy and the public was somewhat prepared for drastic changes and hardship, trusting it would lead to a better future [Angresano at al., 1996], [Porzecanski, 2006]. The Polish debt crisis begun as early as 1981 .The unpaid amounts were repeatedly rescheduled from that time. Interestingly debt reduction did not happen immediately after the non-communist government took over in 1989. It was only after Poland implemented its shock reform-program and agreed a three year adjustment plan with the IMF that the Paris Club decided to support Poland's efforts. It was acknowledged that the refinancing and restructuring alone could not change the debt-to-GDP ratio and that the Polish economy would not revive with the amounts of debt already accumulated. The debt reduction created a foundation for implementation of the profound and difficult (socially and politically) adjustment program required by the IMF as part of the debt agreement. Although the adjustment policies were very difficult to implement they paved the way for economic stabilization and growth. It was also important that they were accompanied by new money from the IMF and other international sources.

Despite the new challenges generated by the growing use of bond the debt reorganizations of the 1990s proved that sovereign and private bond restructurings are possible even without collective action clauses, as it was in the cases of Pakistan, Ukraine, Russia, Ecuador and Argentina. And there were bail-ins of interbank lines in the cases of Korea, Indonesia, Thailand, Russia, Brazil, and Turkey [Kindleberger at al., 2000]. In all cases there was fear of contagion, which aggravated the extensive financial crisis which in turn speeded up the negotiation process. It became apparent that greater private sector involvement in the debt reorganisation could be achieved when an "arbiter" (usually an international financial institution) who could provide the additional funds required was involved [Radelet at al., 1998].

A Bank of England working paper declared in 2004 that new era in sovereign debt financing had begun. "In February 2003, Mexico made a policy decision to include collective action clauses (CACs) in its sovereign bonds issued under New York law, contrary to market convention. With the first-mover problem solved, most other emerging markets issuing in New York have followed suit. A new market standard for emerging market sovereign bonds appears to have been set, with CACs as its centrepiece" [Haldane at al., 2004].

In theory, all sovereign obligations are part of one great accumulation of senior unsecured debt, where all creditors are equal under law. While applying different priority criteria to official and private debt is reasonable, given 
their different functions, restructuring a debt stock that includes both poses an administrative challenge. One way to resolve the problem is to pick one scale over the other, for example, subordinating all official debt to all private debt, or vice versa. Related to this is the distinction which stems from the fact that insolvent states have no recourse to a bankruptcy process that could give them meaningful financial relief and their creditors reasonable assurance of fair treatment.

There are two separate constituencies to consider when the financial sector is directly involved in any debt reorganization, since the perspectives of the foreign banks and the indebted country public sector are different. The stability of the domestic financial sector can be threatened if the domestic private banking sector is forced to incur losses through debt reduction at a level equal to that for foreign banks. Destabilization of the banking sector coerces public involvement and thus further increases the public debt of the economy which has declared insolvency. For the future economic performance of the indebted country a bailout without its component of private sector involvement in the domestic market might improve the chances of implementing the necessary policy changes in the debt-laden economy. However it could also create unwelcome moral hazard situation where the financial sector is continuously rescued with the public money. As a result taxpayers would have to pay a forfeit because of the improper financial policy conducted by the governmental bodies.

\section{The forgotten lessons}

From the history lessons it becomes obvious that refinancing (a bailout) or restructuring is a failure as it is very often only a short term solution. It could eventually manage the debt problem if the economy is suffering liquidity rather than insolvency problems. Bailouts currently in the European Union seem to be less expensive than bail-ins because of the interconnectedness of the financial sectors today, combined with their structure and the fragility of their balances ${ }^{10}$. It should be kept in mind, however, that the ultimate success of a bailout depends upon the continuous availability of sufficiently large resources and the correctness of the adjustment programs which should be implemented in the debtor countries and which should lead to their sustainable GDP growth. If programs are too soft further sources will be needed, while if they are excessively harsh they might become politically unfeasible. And if they are not accompanied with the new money supporting policy changes they usually fail [Baldwin at al., 2010].

Debt reduction involves far more difficult preconditions. First and foremost is political will. Both sides must also agree on the causes of the debt problem (e.g. deciding if the debt is due to insolvency or illiquidity) and find the way to remove the predicaments. To achieve this compromise the parties involved must have the opportunity to express their wishes through a common platform

10 Stress test of the European banks are still not credible - see also Table 2. 
which would create a "room" for negotiations. Debt negotiations are politically very sensitive. They have been conducted through various multilateral platforms including the "Paris Club" and the "London Club"11. When the current debt situation in the eurozone arose, the EU did not have the appropriate platform which could serve as a room for debt negotiations.

A consensus emerged at the end of the last century that optimal debt relief for developing countries should include 'stock and flow' operations ensuring that a country is able to meet future debt service obligations without unduly compromising economic growth. A second condition of the international consensus was that a creditor should contribute to the security of the international financial system in order to safeguard the new inflows required to sustain the GDP growth in the future. The necessary funds needed to comply with these conditions used to be supplied by the IMF. The IMF remained a crucial participant throughout the 1980s and 1990s in all debt negotiations. It acted on behalf of the creditor states as a mediator and a debt manager which tried to combine two objectives: to recover as much of the outstanding debt as possible, and to design an adjustment program acceptable to the debtor [Boughton, 2004].

From the past we have learned that debt sustainability depends on the continued growth of the economy. Exclusive emphasis on restoring sound public finances will not suffice. Everybody seems to agree that Europe's debt can only be sustainable if current debt-to-GDP ratios can be reduced. But most of the focus to date has been only on the one part of the equation - reducing the growth of public debt. While it is important, the most critical factor in the long run is the restoration of GDP growth. Therefore, a broader political deal on economic policies and economic governance is needed to lift growth and restore confidence in the future of the eurozone and the European Union.

If the debt reorganization is to be successful, the governments involved will have to make the macroeconomic adjustments. The real problems lay not only in the macroeconomic adjustments of the indebted counties but also in the adjustments of the rescue mechanisms and adjustment of the eurozone and to the functioning European Union.

Three well-known issues are present in nearly all debt negotiations: conditionality, equal treatment and moral hazard. Conditionality is designed to assure the creditors that debt can be repaid after rearrangement. However framing the conditions should not shift the whole burden only on the shoulders of the debt laden country. Equal treatment addresses the question of identical burden sharing by the creditors. The moral hazard issue is often raised by the creditors who express their concern that other debtors in the future will

11 The Paris Club is the informal gathering of the creditor states representatives who decide, under Presidency of the French Treasury, how to resolve the public debt problems of the borrower. Similarly, the London Club is an informal association of private creditors (banks) used to dealing with the private non - guaranteed credits. World Bank, OECD chaired also in the past aid consortia - e.g. for Pakistan, India, Turkey debt negotiations. 
exploit examples of not fulfilling their obligation to repay ${ }^{12}$. It thus always shifts the whole responsibility of the ensuing situation onto the shoulders of the debtor and is always raised by parties who are reluctant to support debt relief decisions, making it very effective in delaying the process. In fact, moral hazard reservations have probably overshadowed the present eurozone debt discussions and may be a key reason why rescue funds were not set up when the eurozone was created.

All these provisions were resolved so far in the successful debt reorganisations. But they are almost not addressed in the present eurozone debt management activities.

\section{The unresolved problems in the eurozone}

These lessons appear to be forgotten in the present debt management in the eurozone. For the time being in Europe there is a lack of concerted political agreement as to the fundamental changes of the economic architecture of the European Union. There is still no consensus about the sources and possible consequences. With the benefit of hindsight, one can name different causes of the present debt situation in the eurozone.

It is now clear that deficit discipline has been lacking in all almost all EU countries. From 2000 to 2007, Greece violated the 3\% rule in every year. Others also disregarded it including Italy (five times), Portugal and Germany (four times) and France (three times). In Greece the general government cumulative net borrowing between 2000 and 2008 amounted to 95\% of its GDP; Portugal followed at $32.2 \%$. Ireland, on the other hand, had a $4.3 \%$ surplus and Spain was close to break-even with a cumulative deficit of $1.9 \%$.

In this period, while the eurozone's overall trade accounts remained in balance, the PIGS (Portugal, Ireland, Greece and Spain) experienced very large deficits, offset by large surpluses in the core eurozone economies. Cumulative current account balances as a proportion of GDP for the whole euro area in the period 2000-2007 amounted to 3.3\% whereas cumulative deficits for the PIGS countries represented $198.6 \%$ of their GDP ${ }^{13}$. So it is noticeable that the classical twin deficits were one of the culprits of the present debt situation [Blanchard, 2002]. European Commission must have observed these development even before the world financial crisis begun but cannot or did not want to step in effectively.

Adverse selection allowed the creditors in the peripheral countries to profit from the fact that the sovereign spreads they had to pay did not reflected the currency and solvency risk. The private sector determined (without the resistance from the regulatory bodies) that "government's fiscal liabilities are

12 This is probably the reason, why in the present crisis, core countries reject the bay-back idea.

13 According to OECD Annex Table 51 http://www.oecd.org/document/61/0,3343,en_2649_34573_ 2483901_1_1_1_1,00.html. That effect was already predicted by Blanchard at al in 2002 
perceived as guaranteed by the rest of the EMU members. The above give rise to three possible regimes for private expectations. In the first regime markets perceive the country's EMU participation as fully credible and outstanding fiscal liabilities fully guaranteed" [Arghyrou at al., 2011].Thus it is apparent that ECB, national banks and financial market regulators failed. Irish, Greek, Spanish, Portugal, Italian and French banks aggressively expanded lending with the silent consent of national and international authorities (ECOFIN, ECB, Basel Committee on Banking Supervision) authorities. Overconfidence in the self-adjusting ability of financial system led to underestimating the consequence of the accumulation of the debt and leverage which resulted from booming credit and assets prices [Galati at al., 2011].

Banks gathered deposits from German and other core countries markets and lend them out to fast-living consumers and companies on Europe's periphery. That appeared to involve taking credit risk, but not currency or country risk. The result has been a surge in cross-border lending.

Table 1

Foreign exposures to Greece, Ireland, Portugal, Spain by bank nationality*

(Euro Billion 2 quarter 2010)

\begin{tabular}{|l|c|r|r|r|r|r|r|r|r|r|}
\hline & Germany & Spain & France & Italy & $\begin{array}{r}\text { Other } \\
\text { EA }\end{array}$ & UK & JAP & USA & ROW & Total \\
\hline Public sector & 48,80 & 7,29 & 64,28 & 5,57 & 34,31 & 14,66 & 10,32 & 6,80 & 6,39 & 242,40 \\
\hline+ Banks & 123,15 & 8,43 & 68,53 & 12,69 & 51,83 & 54,94 & 5,57 & 37,58 & 19,08 & 466,50 \\
\hline $\begin{array}{l}+ \text { Non-bank } \\
\text { private }\end{array}$ & 150,99 & 60,10 & 118,32 & 22,60 & 123,56 & 152,05 & 22,76 & 54,04 & 34,31 & 901,80 \\
\hline $\begin{array}{l}\text { + Unallocated } \\
\text { sector }\end{array}$ & 0,00 & 0,00 & 0,00 & 0,41 & 0,25 & 0,00 & 0,00 & 0,00 & 1,23 & 2,30 \\
\hline $\begin{array}{l}\text { = Total foreign } \\
\text { claims }\end{array}$ & $\mathbf{3 2 2 , 7 7}$ & $\mathbf{7 5 , 9 0}$ & $\mathbf{2 5 1 , 2 1}$ & $\mathbf{4 1 , 2 7}$ & $\mathbf{2 1 0 , 0 2}$ & $\mathbf{2 2 1 , 5 7}$ & $\mathbf{3 8 , 5 7}$ & $\mathbf{9 8 , 4 2}$ & $\mathbf{6 1 , 0 0}$ & $\mathbf{1} \mathbf{6 1 3 , 0 0}$ \\
\hline $\begin{array}{l}\text { + Other } \\
\text { exposures** }\end{array}$ & 96,95 & 20,31 & 84,58 & 21,29 & 20,14 & 81,31 & 4,01 & 190,53 & 28,17 & 668,20 \\
\hline = Total exposures & $\mathbf{4 1 9 , 8 0}$ & $\mathbf{9 6 , 0 5}$ & $\mathbf{3 3 5 , 8 7}$ & $\mathbf{6 2 , 4 7}$ & $\mathbf{2 3 0 , 1 6}$ & $\mathbf{3 0 2 , 9 6}$ & $\mathbf{4 2 , 5 8}$ & $\mathbf{2 8 8 , 9 5}$ & $\mathbf{8 9 , 2 5}$ & $\mathbf{2} \mathbf{2 8 1 , 3 0}$ \\
\hline
\end{tabular}

* Exposures of banks headquartered in the respective country are not included, as these are not foreign exposures. ${ }^{* *}$ Positive market value of derivative contracts, guarantees extended and credit commitments.

Source: Author's calculations based on the Bank for International Settlements SDW data, http:// www.bis.org/statistics/bankstats.htm

Ireland's total bank assets as a percent of GDP soared from 360\% in 2001 to $705 \%$ in $2007^{14}$. French banks grew their books by $60 \%$, Spanish banks were similar and Italian banks were up by 50\%.During the last 10 years (through the 2 quarter of 2010) the bank of eurozone exposure to the PIGS rose from EUR 200 billion to ca EUR 1144 billion (see table 1). As a result of the rapid growth in lending combined with falling capital ratios, European

14 According to BIS Consolidated Banking Statistics from June 2010. 
banks will have to refinance EUR 1.7 trillion over the coming three years ${ }^{15}$. Around EUR 1.8 trillion of EU bank debt is due to mature over the next two years through the end-2012 16 .

While on average the eurozone nation has debt stock of about $80 \%$ of its GDP, its banks hold liabilities many times larger. In 2010, German bank debt was over $300 \%$ of Germany's GDP - see Tables 2 below ${ }^{17}$. French, Spanish, and Belgium banks are in a similar situation. The corresponding figure for Ireland is over $900 \%$.

Table 2

Total liabilities of the monetary financial institutions (MFI) and the country GDP

(EUR billions 2010)

\begin{tabular}{|l|r|r|r|r|r|r|r|r|r|}
\hline & Ireland & Spain & Portugal & Belgium & Germany & France & Poland & Greece & Italy \\
\hline $\begin{array}{l}\text { Capital } \\
\text { and reserves }\end{array}$ & 111,1 & 279,8 & 42,9 & 56,3 & 380,6 & 476,7 & 42,0 & 44,0 & 348,0 \\
\hline Total liabilities & 1416,0 & 3195,6 & 518,6 & 1079,7 & 7924,1 & 7353,4 & 269,1 & 470,1 & 3448,0 \\
\hline GDP & 156,5 & 1051,3 & 171,4 & 351,9 & 2489,5 & 1947,8 & 354,7 & 229,9 & 1548,3 \\
\hline $\begin{array}{l}\text { Total liabilities } \\
\text { to GDP }\end{array}$ & 9,05 & 3,04 & 3,03 & 3,07 & 3,18 & 3,78 & 0,76 & 2,04 & 2,23 \\
\hline $\begin{array}{l}\text { Capital + } \\
\text { reserves/total } \\
\text { assets in 2010 }\end{array}$ & $7,3 \%$ & $8,0 \%$ & $7,6 \%$ & $5,0 \%$ & $4,6 \%$ & $6,1 \%$ & $13,5 \%$ & $8,5 \%$ & $9,2 \%$ \\
\hline $\begin{array}{l}\text { Capital + } \\
\text { reserves/total } \\
\text { assets in 2007 }\end{array}$ & $4,3 \%$ & $7,1 \%$ & $7,6 \%$ & $4,4 \%$ & $4,8 \%$ & $5,4 \%$ & $10,7 \%$ & $6,1 \%$ & $7,5 \%$ \\
\hline
\end{tabular}

Sources: Author's estimates on ECB Statistical Data Warehouse and AMECO data

The above data also shows the weak capital positions of peripheral MFI's as well as MIF'S of eurozone core countries.

The booming economic performance in Greece, Ireland, and Spain was accompanied by prices that rose much more than average. Uneven inflation rates with a uniform interest rate policy ${ }^{18}$ produced real interest rate differences that caused divergent trends. The difference between the level of interest rate established by ECB and the level which could have been accepted according to the Taylor rule was striking in the peripheral countries. Before the crisis the ECB interest rates for the peripheral economies were too low now they are too high. And will be even higher when the ECB rises the interest rates unwinding the special measures used for combating the last global financial crisis and taming

15 Wall street Journal, February, 16 2011http://online.wsj.com/article/SB1000142405274870440 $9004576146550772203610 . \mathrm{html}$ ?mod=WSJEUROPE_hpp_MIDDLETopNews

$16 \mathrm{http}: / /$ www.publications.parliament.uk/pa/cm201011/cmselect/cmeuleg/428-xiv/42804.htm

17 In some tables data for Poland is also presented as Poland is the biggest of new EU countries.

18 The results of the convergence of short and long term interest rates were presented by G. Fagan and V. Gaspar already in 2007 [Fagan at al., 2007]. 
inflation. Borrowers in Ireland and Spain, Portugal faced negative real interest rates that fuelled investment in assets such as housing. Germany's lower than average inflation, in contrast, produced relatively high real interest rates that had the opposite effect. Rapidly growing consumption and real estate booms financed by private debt emerged in a number of EU member countries but especially in Ireland and Spain ${ }^{19}$. This led to sharp price and wage increases, undermining competitiveness and leading to large current account deficits.

With growing credit activities economies of the peripheral countries become more dependent on the credit supply. So called credit impulse (relation between credit and GDP) in the period 2000-2007 grew in Greece by 1.89 times, in Ireland by 1.84, in Spain by 1.84. In Portugal that increase amounted to 1.27, almost as in France but was 50\% higher then in Germany.

It is also worth stressing that in the last 10 years, the peripheral countries have been losing their competitiveness as measured by REER ULC deflated (unit labour costs) and weakened their productivity-compensation ${ }^{20}$ ratios $(2000=100)$ measured as the relationship between productivity and compensation. The peripheral countries while increasing their debt burden were losing competitiveness (see table 3).

Table 3

Competitiveness change in some eurozone countries (+ decrease)

\begin{tabular}{|c|c|c|c|c|c|c|c|c|c|c|}
\hline $\begin{array}{l}\text { REER } \\
\text { ULC }\end{array}$ & 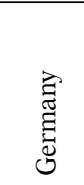 & $\begin{array}{l}\vec{Z} \\
\frac{\vec{\sigma}}{0} \\
0\end{array}$ & 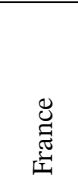 & 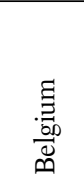 & 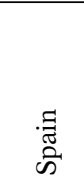 & 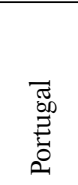 & 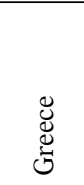 & 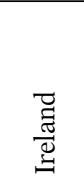 & 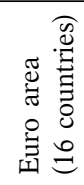 & 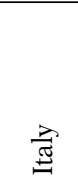 \\
\hline $2011 / 2000$ & $-4,2 \%$ & $1,6 \%$ & $12,2 \%$ & $13,0 \%$ & $16,3 \%$ & $16,4 \%$ & $16,7 \%$ & $20,5 \%$ & $22,3 \%$ & $25,3 \%$ \\
\hline $2011 / 2007$ & $-0,5 \%$ & $3,5 \%$ & $0,1 \%$ & $3,6 \%$ & $-1,4 \%$ & $4,7 \%$ & $3,6 \%$ & $-6,5 \%$ & $2,5 \%$ & $4,5 \%$ \\
\hline
\end{tabular}

Source: Author's calculation based on EU AMECO, BIS SDW data

Having in mind the structure of the balance sheets of the banking system in the European Union, one can argue that the real problem in the eurozone was in fact an extraordinary rise in private, not public, debt [De Grauwe]. That inference could be supported by the fact that before the financial crisis, Ireland and Spain were held up as models of responsible fiscal policy. Ireland's debt-to-GDP ratio was reduced in the period 2000-2007 by 13 percentage points to $25 \%$ of GDP, while Spain in the same period slashed its debt by 23 percentage points to $36 \%$. It can be seen that since 2004 banks' liabilities have grown more than those of the general government in the eurozone as a whole. But the problem lies in the structure of the bank's inflated assets and

19 According to Goldman Sachs Spanish institutions have exposure to more than $€ 100$ billion of empty plots, either as lender or owner.

20 REER ULC Performance relative to 20 industrial countries (CZ DK EE LV LT HU PL SE UK BG RO TR CH NO US CA MX JP AU NZ).Productivity is defined as GDP divided by employment and real compensation per employee is calculated on AMECO data. 
the fact that an important share of these assets was used to finance budget deficits in different European Union countries (see table 4).

Table 4

MFI credit increase to the public sector ("sovereign risk" activity)

\begin{tabular}{|l|c|c|c|c|c|c|c|}
\hline & Germany & Spain & France & Greece & Ireland & Italy & Portugal \\
\hline 2q.2011/2000 & 0,853 & 2,645 & 1,832 & 4,269 & 7,350 & 4,270 & 5,033 \\
\hline $2007 / 2000$ & 0,757 & 1,370 & 1,522 & 4,096 & 1,656 & 3,652 & 2,672 \\
\hline
\end{tabular}

Sources: Authors calculations, ECB SDW data

On the other hand one can construct a hypothesis, based on the simple analysis of macroeconomic data supplied by ECFIN and AMECO, that private debt accumulation (which happened mainly in the financial sector) took place not because of investment activity but in order to finance the social safety nets of the now troubled countries. Table 5 below shows the relationship between tax burden (\% GDP) of each of the selected country and the difference between their annual increases in social transfer and GDP growth ${ }^{21}$, capital expenditure annual growth and the debt-to-GDP ratio level changes pre-and-post crisis. The countries are listed according to their average tax rates and all data is calculated, as an average, for the period from 2000 to 2008 so as to avoid the influence of the world financial crisis.

Table 5

General government revenue, expenditure, budget balances and gross debt

\begin{tabular}{|c|c|c|c|c|c|c|c|c|}
\hline & 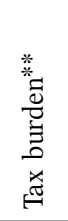 & 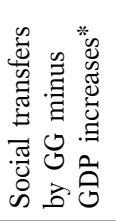 & 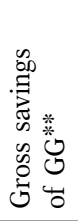 & 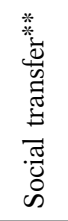 & 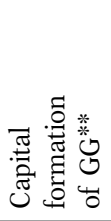 & 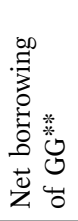 & 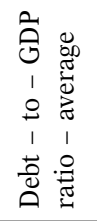 & 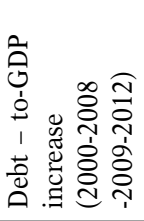 \\
\hline Ireland & 30,4 & 5,1 & 4,2 & 11,1 & 5,1 & 0,4 & 31,93 & 64,12 \\
\hline Portugal & 31,9 & 4,1 & $-1,3$ & 17,5 & 3,6 & $-3,7$ & 57,62 & 27,40 \\
\hline Greece & 32,3 & 3,4 & $-2,9$ & 16,5 & 8,9 & $-11,9$ & 102,98 & 40,32 \\
\hline Poland & 33,1 & $-0,3$ & $-0,1$ & 17,8 & 4,3 & $-4,4$ & 44,03 & 11,77 \\
\hline Spain & 34,7 & 1,0 & 4,2 & 14,3 & 9,3 & $-0,3$ & 46,74 & 18,33 \\
\hline Germany & 39,5 & $-0,9$ & 0,2 & 25,5 & 2,9 & $-2,3$ & 63,93 & 11,12 \\
\hline Italy & 41,8 & 1,5 & 1,0 & 19,7 & 3,9 & $-3,9$ & 106,02 & 10,24 \\
\hline France & 43,5 & 0,6 & 0,9 & 23,0 & 4,1 & $-2,7$ & 62,47 & 21,96 \\
\hline Belgium & 44,3 & 0,4 & 1,8 & 22,4 & 2,9 & $-0,4$ & 93,40 & 5,95 \\
\hline
\end{tabular}

* annual percent changes; **\% GDP; GG represents General Government sector

Source: Author's calculations based on EU AMECO data, World Bank data; except for the last column all data are calculated average for the period 2000-2008

21 Social transfers other than in kind and social transfers in kind via market product; all data average for the given period 2000-2008. 
In almost all countries lower tax rates were accompanied by higher growth rates of social transfers to compare with the GDP growth.

Table 6 shows the correlation between selected data presented in the Table 4 (for the peripheral countries only).

Table 6

Correlation between selected macro data

\begin{tabular}{|c|c|c|c|c|c|}
\hline $\begin{array}{c}\text { Correlation } \\
\text { between: }\end{array}$ & $\begin{array}{c}\text { Social transfers } \\
\text { minus GDP } \\
\text { increases* }\end{array}$ & $\begin{array}{c}\text { Social transfer } \\
\text { increases* }\end{array}$ & $\begin{array}{c}\text { Debt/GDP } \\
\text { ratio }\end{array}$ & $\begin{array}{c}\text { Gross savings } \\
\text { of GG** }\end{array}$ & $\begin{array}{c}\text { Capital } \\
\text { formation } \\
\text { of GG** }\end{array}$ \\
\hline Average tax** & $-0,842$ & 0,846 & 0,634 & 0,105 & $-0,475$ \\
\hline
\end{tabular}

Source: Author's calculations; asterisks as in table 5; average calculation for 2000-2008

The figures show that monetary union created a comfortable space for rather lax fiscal policies. Lower taxes were accompanied by higher than GDP growth in social transfers. Similarly there was a strong correlation between lower tax levels and higher capital expenditure. As mentioned before, the debt-to-GDP ratio in Ireland and Spain was at acceptable levels before the crisis. Nonetheless the social transfer increase in Ireland and Spain was still higher than the GDP growth rate. It was the same in Greece and Portugal. There is little correlation between the tax level and gross saving in the peripheral states.

All these facts became all of a sudden evident after the Greek crisis blew up in the middle of 2010. And that happened only because the new Greek government disclosed the statistical "irregularities" in the figure reported to EUROSTAT. A CME Group Company published cumulative probability of default (CPD) which presents the probability of a restructuring of debt (based on the CDS analysis) [Fontana at al., 2010].

In January 20115 5years CPD for Greece amounted 58,8\%, Ireland followed $41,2 \%$, Portugal 35,9\%, Spain 26,7, Italy 19,3\%, Belgium 17,9\%22. And for the bailout countries that probability is still rising.

\section{The current actions and their possible consequences}

By December 2009, Greece's debt had reached the level of EUR 300 billion according to its Ministry of Finance. To put that in perspective, Greece then owed more than five times the amount that Russia owed when it defaulted in 1998 and twice as much as Argentina owed when it missed payments in 2001 and the Polish official debt, when reorganized, amounted to over 50\% of GDP.

As early as February 2010, Germany tried to oppose a quick bailout of Greece, saying the country must tackle its debt problems itself. But one of the key issues preventing eurozone leaders from letting Greece face its debt

22 http://www.cmavision.com/images/uploads/docs/CMA_Global_Sovereign_Credit_Risk_Report_ Q4_2010.pdf 
struggle unaided was the problem of the interconnectedness of the banking system in the eurozone. Failure in Greece, especially if it triggered problems in other countries, threatens to cause a systemic banking crisis [Feldstein, 1991], [Eichengreen, 2004] in the eurozone core nations, including Germany, France, and Austria. The risk of double dip was somehow justified as the uncontrolled "debt event" in Greece might have also impacted the new European countries as well caused a Lehman-like financial failure.

When the Greek crises erupted, although occasional and expensive rescue actions have been implemented over the past years (in Greece in Ireland in Portugal), the most controversial question in the debate on the reform of the international financial architecture has not yet been resolved. This is the question of involving the private sector in the resolution of the crisis. Last year bank stress tests showed that bailing out sovereign debtors in the eurozone by bailing-in creditors (banks) will, in the present circumstances, end up involving the public money of the core eurozone countries. It is apparent that the financial institutions holding sovereign bonds have not yet create sufficient balance sheet reserves. Hastily the European Financial Stability Fund has been created to resolve the peripheral countries debt problems in the form of bailouts. By the end of 2010, the creation of a European Stability Mechanism was announced. The ESM is designed to restore economic soundness to the European economies within a couple of years. Ipso facto the public authorities of the eurozone somehow put themselves into the "lenders' trap" position, known since Latin America debt crisis. At present no one knows what the price of debt restructuring carried out now will be and what it would cost in the future if bailout action were unsuccessful.

There are many different political bodies involved - European Commission, Council of Ministers, ECB, IMF and from time to time European Council (EU leaders) summits - which conduct negotiations with the troubled governments. Each of this bodies supports its own goal as every one has its particular mission to accomplish. As a result no serious adjustment programs were negotiated as a precondition for the bailout assistance. Serious programs should assume not only refinancing or rescheduling of the debt but also create conditions allowing for further growth, to allow the indebted country to service the obligations after the deal is done. These programs should be based upon policy measures after they are accepted by the proper authorities of the countries involved. The Economic Adjustment Program for Greek form February 2011 (Occasional Papers 77) ECFIN do not covers all fields needed for successful debt reorganisation. After a year of wages cuts, tax increases and other austerity, Greece ended 2010 with the euro-region's second highest deficit at 10.5 percent of gross domestic product and the highest debt at 143 percent of GDP.

Unfortunately current "solutions" are creating even bigger problems for the European Union in the future as old indebtedness is compounded with new debt. It will become more difficult politically and more costly to fix the problems as time goes by. The citizens of the debt-laden countries are now being asked to make significant sacrifices for "adjustment plans" which will not 
solve the problem. Political capital is being wasted by this piecemeal process as well and there might not be enough support for future adjustments ${ }^{23}$. On the other hand, core countries perceive the bailouts as a kind of sacrifice and do not accept their part in that game. The money committed for the bailout activity will eventually amounts to EUR 900 billion (for the EFSF - EUR 440 billion and EUR 500 billion ESM mechanisms). This money must come from the budgetary sources which will burden private sectors also in the solvent countries either by tax increases or by reduced public sector expenditures.

The bail outs in peripheral countries are being conducted under the assumption that the markets will allow these economies to return to the market only with slightly worse conditions than they had previously and the so called "sovereign risk hypothesis" prevails. Because the key concern at the moment is putting forward the austerity measures, less attention is given to growth problems. However if growth is slow in the next few years there will be a race between growth, implicit interest and primary deficit/surplus. And as the ECB unwinds its special policy, the interest levels will rise and a new austerity measures will have to be implemented to balance the budget. Privatisation could be of some help if there is political support and market acceptance. But the size of the suggested selling off the state assets (EUR 50 billion for Greek) in such a short period of time is doubtful ${ }^{24}$. And shows the amount of money needed, on top of the already declared by EU and IMF sums, to prevent default. For the time being the 2010 results and the 2011 European Commission forecast clearly show that the peripheral countries are getting into even bigger troubles as debt and unemployment are growing, deficits stay at the level not less then 5\% of GDP and far above declared targets, and GDP is falling (Greece, Portugal) or only slightly rising (over one percent in case of Spain and Ireland).

It is also highly probable that the debt-to-GDP ratio problems in the peripheral countries will be transformed into debt service-to-public sector revenue issues (see table 7).

Table 7

Public sector debt compared with the public sector income

\begin{tabular}{|l|c|c|c|c|c|c|c|c|}
\hline & Belgia & Niemcy & Irlandia & Grecja & Hiszpania & Francja & Włochy & Portugalia \\
\hline $2010 / 2007$ & $111,3 \%$ & $115,6 \%$ & $447,9 \%$ & $122,4 \%$ & $193,6 \%$ & $125,7 \%$ & $109,8 \%$ & $120,4 \%$ \\
\hline $2012 / 2007$ & $110,8 \%$ & $113,1 \%$ & $515,7 \%$ & $127,6 \%$ & $210,0 \%$ & $130,9 \%$ & $107,5 \%$ & $138,9 \%$ \\
\hline
\end{tabular}

Sources: Authors calculation based on ECFIN (November 2010) data

That could easily be the case if euro area bond markets continue to exhibit wide spreads. Governments would only be able to roll over their payments at

23 February (2011) riots In Greece show how sensitive the adjustment program could be; in March Fitch further downgraded Greece rating.

24 Especially Germany urge the vast privatization; see for instance Die Welt, 14 May 2011 "Griechischer Staat sitzt auf einem riesigen Vermögen". 
the higher costs. The debt will lose the "characteristics of government bonds" unless some level of debt reduction happens and corporate credits will follow suit. Debt relief will ultimately be required as the "new debt" will grow much faster than the projected real GDP growth and the debt-to-GDP ratios rises [Cecchetti at al., 2010], [Escolano, 2010].

The fiscal programs, if excessively implemented, will decrease consumption and put further downward pressure on GDP growth and the public sector revenues. Investments might be financed by FDI but both investments and exports would depend on the rise of competitiveness. However, that again requires price deflation and wage control, both socially painful and politically risky. The peripheral countries problems lie not only in the accumulated big twin deficits or lost competitiveness. The most difficult problem boils down to the fact that the eurozone has offered its members a sort of a "free lunch" in the past 10 years (see tables 5 and 6).

Central to the final resolution of any debt crisis is always the creditors' and debtors' perception of their roles and their need to cooperate. The controversy in this context depends on whether creditors take some of the blame for loose lending and whether debtor countries accept responsibility for excessive borrowing and macroeconomic mismanagement. Although it seems that the future existence of the eurozone is at stake, many participants have not abandoned the illusion that they can solve the EMU debt problems without incurring costs. Until now all parties are trying to postpone the moment of final negotiations. The European Commission presented plans for fundamental treaty changes that will extend the current aid mechanism - the European Financial Stability Facility. They are assuming that the bailout will continue up to 2013.

At the same time the development plans each country officially declared through 2014 or 2015 show that the debt-to- GDP ratios will increase for almost all countries in question. Accepting the forecasted GDP and debt-to-GDP ratio as given by ECFIN 25 the nominal debt level of PIGS will rise by EUR 218 billion between 2010 and $2012^{26}$. That funding requirement should be covered by the market or by the EFSF ${ }^{27}$. However, the markets will not be deceived. Five years from now currently insolvent economies will not be in better shape for debt negotiations than they are today after implementing Ponzi financing schemes. This will be true even if the effective EFSF mechanism grows to be larger than it is today.

The rationale behind the present bailout actions could be understood as buying time for the financial system to improve the core countries bank's balance sheets as their exposure to the PIGS is higher than their capital. In the middle of 2010, the exposure of twelve eurozone countries banks to Greece, Ireland, Portugal, Spanish banks and their public sectors was approximately

25 The ECFIN date were based on the accepted by the competent authorities; so the changes must also get appropriations committees approval.

26 General government debt of these countries will amount to ca EUR 1500 billion in 2012.

27 If Portugal requests rescue funds at EUR 70 billion that will surpass lending capacity of EFSF (Greece - EUR 110 billion and Ireland EUR 67,5 billion). 
EUR 410 billion. Ex eurozone countries exposure was about EUR 263 billion. If a debt reduction were to happen, it would not only create funding problems but also raise questions about equal treatment between eurozone, non eurozone members of EU and the rest of world, as well as rising moral hazard concerns as the non-bank private debt of these countries amounts to 50\% of total foreign claims vis-à-vis the four peripheral economies. At the end of 2010 ECB exposure to the Greek banks amounted to EUR 98 billion, Ireland EUR 94,6 billion, Portugal EUR 42 billion and Spain EUR 61,6 billion. The impact on banks of a collapse would depend not only on the size of exposures, but also on the quality of collateral, the solidity of the counterparties with whom hedges have been taken out, and whether local money had been used to fund loans. Better positioned, particularly against the risk of devaluation, are firms with subsidiaries that have their own capital, deposits and debt. That could be the reason ECB opposes to restructure the debt- laden countries debt.

For the time being the most important issue boils down to the structure of the second rescue package for Greece (to be decided after summer holidays). In that particular case it is at this time not the problem how vast the central eurozone countries involvement should be and how acute the saving measures of the Greek authorities should be implemented. At last two most important measure will be addressed - it means the private sector involvement in the haircut decisions (because the debt reduction - through that or another way - is inevitable, as the debt is too big for the debtor to handle on a sustained basis ${ }^{28}$ ) and/or the chance Greece leaving the Euro zone (trade - off for the eurozone as well as Greece). These issues, although still perceived mostly through the financial sectors eyes, take more and more into consideration the taxpayers view.

At present one does not see any political willingness, on both sides to discuss debt reduction. Debt reduction for the bondholders, if similar in form to Brady's, would impact national banks, (not only in the eurozone) to different degrees. Comparability of treatment, and moral hazard issues so closely observed in the past would play an important role. But there are also important questions to be answered about how the various constituencies approach their own financial sectors (banks and non banks) which will have to bear the costs of the debt reduction ${ }^{29}$. They might decide to leave the banks alone to deal with the problem themselves, or they may offer support such as partial nationalization (to fill the gap in the bank's capital) similar to what was done at the beginning of the last financial crisis. In each case (debt reduction and

28 In 1985 [Loomis, 1985], [Barlett, 1985] argued against the measures proposed by the USA (Baker Plan) concerning the debt situation in Latin America, the measures similar to those already applied or proposed in the eurozone debt crisis. The Baker Plan was not implemented.

29 For instance Greece's debt at the end of last year was about EUR340 billion of which about EUR 80 billion is held by Greek banks and funds, and around EUR50 billion by the European Central Bank, with the remaining in private hands. The European Union and IMF so far have given the country about EUR50 billion as part of the EUR110 billion bailout plan. 
rescheduling), the eurozone banks will take a haircut which will influence the resilience of the financial systems of the creditors. The eurozone governments will all have to make tough political decisions about the level of public involvement in the whole process - far above already declared lending capacity of ESFS and $\mathrm{ESM}^{30}$.

\section{Bibliography}

Arghyrou A.G., Kontonikas A., [2011], The EMU sovereign debt crisis: Fundamentals, expectations and contagion, European Commision, Economic Paper 436.

Angresano J., [1996], Poland After the Shock, Albertson College of Idaho, Comparative Economic Studies, Vol. 38 No. 2/3.

Baldwin R., Gros D., Laeven L., [2010], Completing the euro zone Rescue: What More Needs to be done?, Centre for Economic Policy Research, http://www.voxeu.org/index.php?q=node/5192

Barlett B. at al., [1985], The promises and pitfalls of Bakers third world debt plan, Heritage Foundation, http://www.heritage.org/research/reports/1985/12/the-promise-and-pitfalls-ofbakers-third-world-debt-plan

Béranger-Lachand S., Eugène Ch., [2001], Banque de France, Bulletin Digest, No. 86.

Berry Ch.G., [2006], Corporate restructuring and bankruptcy, New York Time Journal.

Blanchard O., Giavazzi F., [2002], Current Account Deficits in the Euro Area: The end of the Feldstein-Horioka Puzzle, Brookings Papers on Economic Activity, 2.

Boughton J.M., [2004], The IMF and the Force of History: Ten Events and Ten Ideas That Have Shaped the Institution, MF working paper.

Cecchetti S.G., Mohanty M.S., Zampolli F., [2010], The future of public debt: prospects and implications, BIS Working Papers No. 300.

De Grauwe P., Fighting the wrong enemy, [2010], http://www.voxeu.org/index. php?q=node/5062.

Eichengreen B., [2004], Financial instability in global crisis, global solutions, Cambridge University Press.

Escolano J., [2010], A Practical Guide to Public Debt Dynamics, Fiscal Sustainability, and Cyclical Adjustment of Budgetary Aggregates, IMF.

Fagan G., Gaspar V., [2007], Adjusting to the euro, ECB Working Paper Series, No. 716.

Feldstein M., [1991], The risk of economic crisis, The University of Chicago Press, pp. 1-42.

Fontana A., Scheicher M., [2010], An analysis of euro area Sovereign CDS and their relations with Government bonds, ECB, http://www.ecb.int/pub/pdf/scpwps/ecbwp1271.pdf

Fukuda K.H., [2008], What Is a Vulture Fund?, http://blogs.law.uiowa.edu/ebook/faqs/what-is-avulture-fund

Galati G., Moessner R., [2011], Macroprudential policy - a literature review, BIS working paper No. 337.

Gelpern A., [2007], Odious, Not Debt, http:/Law.Duke.Edu/Journals/Lcp

Helleiner G.K., [April 1989], The Sub-Saharan African Debt Problem: Issues For International Policy, Unpublished, Toronto: University Of Toronto.

Haldane A. at al., [2004], Optimal collective action clause thresholds, Bank of England, Working Paper No. 249.

30 Cash contributions to the European Stability Mechanism, will amount to EUR 80 billion spread over five equal annual installments. Another EUR 620 billion will be callable, to give the fund an AAA rating - according to the presented arrangements. 
Hornbeck J.F., [2004], Argentina's Sovereign Debt Restructuring, CRS Report for Congress, http:// fpc.state.gov/documents/organization/39301.pdf

Kalonga P., [1999], Paris Club Debt Relief, Multilateral Frameworks and Implications for Poor Country debt Department of Economics, University Of Surrey.

Kindlebereger Ch., Aliber R., [2000], Manias, Panics, and Crashes, John Wiley \& Sons, Inc. pp. 275-303.

Krueger A., [2001], A New Approach to Sovereign Debt Restructuring, speech to the IMF, http:// blogs.law.uiowa.edu/ebook/faqs/what-is-a-vulture-fund

Krugman P., [1998], Market based Debt reduction schemes, NBER Working Papers 2587, Financing versus forgiving a debt overhang, NBER Working Papers 2486, http://ideas.repec.org/p/nbr/ nberwo/2587.html

Loomis C.J. at al., [1985], Why baker's debt plan won't work, Fortune, http://money.cnn.com/magazines/fortune/fortune_archive/1985/12/23/66805/index.htm

Miller M., Zhang Lei, [1999], “Sovereign Liquidity Crisis: The Strategic Case for a Payments Standstill” CSGR Working Paper No. 35/99.

Porzecanski A.C., [2006], Private vs. Offcial Creditors: The Record Speaks, American University.

Radelet S., Sachs G., [1998], The onset of the East Asian Financial Crisis, NBEER Working Paper 6680.

Reinhard C., Rogoff K.S., [2009], This time is different, Princenton Univerity Press.

Roubini N., [2010], Bail-ins, Bailouts, Burden Sharing and Private Sector Involvement in Crisis Resolution, Stern School of Business, New York University.

Roubini N., Setser B., [2004], Bailouts or bail-ins? responding to financial crises in emerging economies, Institute for International Economics.

Sawicki J., [2010], Znaczenie długu dla zrównoważonego wzrostu gospodarczego, Przykład Polski, Monografie IBRKK, pp. 11-27.

Sachs G., Radelet S., [1999], What Have We Learned, So Far, From the Asian Financial Crisis?, Centre for International Development at Harvard University, http://www.cid.harvard.edu/ archive/hiid/papers.html

Taleb N.N., [2010], The Black Swan, Penguin, page 43.

\section{DEBT REDUCTION IN THE EUROZONE}

\section{Sum mary}

When the Greek crisis exploded in the spring of 2010 the eurozone countries collected funds to refinance Greece's debt in order to stave off a banking crisis. Later Ireland and Portugal asked for similar eurozone assistance. Because refinancing (bailout) was not sufficient to enable these peripheral countries to solve their debt problems, they agreed to implement austerity programs so that they could use eurozone countries' public funds. But these austerity measures, even if politically affordable, will not suffice.

It is exceedingly possible that the peripheral countries will not outgrow their problems and will be unable to return to capital markets at their pre-crisis levels. Their debt-to-GDP as well as debt services-to-income ratios are likely to grow and additional debt reorganization programs including debt reduction (haircut) will be required. At the heart of the issue is the potential impact of a reduction of the peripheral economies' debt on the monetary financial institutions of all European Union countries. As a result of the restructuring and partial debt reduction, banks may need to receive public support. 
To address these problems a new solution in the form of the European Stability Mechanism (EMS) has been proposed. It is expected to change the way in which the eurozone functions. However, the EMS idea is based on the same philosophy as the existing bailout instruments. It does not address the equal treatment and moral hazard issues, while the conditionality programs proposed so far have not softened the adverse impact of the growing debt burden on the economic performance of the debt-laden countries.

The entire European Union financial system is at risk and remains vulnerable as long as the refinancing mechanisms are not supported by debt restructuring and reduction. Debt managers do not seem to know how to draw on past experience and so ad hoc measures prevail. To effectively manage that kind of debt reorganization, the European Union should create the necessary procedures to efficiently address the economic future of all heavily indebted economies. The EU should also be prepared politically to accept the costs of debt reduction or of a fundamental reorganization of the eurozone.

Keywords: sovereign debt crisis, bailout, debt reduction, eurozone, peripheral countries 